\title{
PENGARUH PENGUNGKAPAN CORPORATE SOCIAL RESPONSIBILITY DAN PROFITABILITAS TERHADAP NILAI PERUSAHAAN DENGAN MEDIA EXPOSURE SEBAGAI VARIABEL MODERATING (STUDI PADA PERUSAHAAN PERKEBUNAN YANG TERDAFTAR DI BURSA EFEK INDONESIA, MALAYSIA DAN SINGAPURA PERIODE 2014-2017)
}

\author{
Meri Novita $S^{1)}$, Mukhzarudfa ${ }^{2)}$, Yudi ${ }^{3)}$ \\ ${ }^{1)}$ Alumni Magister Ilmu Akuntansi Pascasarjana Universitas Jambi Tahun 2019 \\ ${ }^{2 \& 3)}$ Dosen Pembimbing
}

\begin{abstract}
This research is aim to obtain empirical evidence about (1) Influence of Corporate Social Responsibility disclosure partially to company value, (2) influence of rofitability partially to value of plantation company, (3) influence of corporate social responsibility disclosure and profitability moderated by disclosure media simultaneously to the value of the company and (4) the values of corporate social responsibility disclosure and profitability moderated by media disclosure on the value of plantation companies going public in Indonesia, Malaysia and Singapore.This type of research is causal explanatory research with the number of research as many as 37 companies. Sampling used purposive sampling technique. The sample of this study is respectable 10 companies. Methods of data analysis using simple regression and multiple regression with MRA.The result of the research shows that (1) Corporate social responsibility disclosure partially to company value, (2) Profitability partially to company statistic, (3) Disclosure of corporate social responsibility and profitability is moderated by media disclosure simultaneously to value of plantation company, and (4) Appears the meaning of corporate social responsibility disclosure and profitability moderated by media disclosure to the value of plantation companies going public in Indonesia, Malaysia dan Singapura. Limitations in this study are the definitions used in reading disclosure reports of accountability because companies have different perspectives in reporting.
\end{abstract}

Keywords: CSR, Profitability, Media Exposure, Company Value

\begin{abstract}
ABSTRAK
Penelitian ini bertujuan untuk mendapatkan bukti empiris tentang (1) Pengaruh Pengungkapan Corporate social responsibility secara parsial terhadap nilai perusahaan perkebunan, (2) pengaruh profitabilitas secara parsial terhadap nilai perusahaan perkebunan, (3) pengaruh pengungkapan Corporate social responsibility dan profitabilitas dimoderasi oleh pengungkapan media secara simultan terhadapnilai perusahaan perkebunandan (4) perbedaan pengaruh pengungkapan Corporate social responsibility dan profitabilitas yang dimoderasi oleh pengungkapan media pada nilai perusahaan perkebunan yang go public di Indonesia, Malaysia, dan Singapura. Jenis penelitian ini yaitu causal explanatory dengan populasi penelitian sebanyak 37 perusahaan.Teknik pengambilan sampel menggunakan teknik purposive sampling. Sampel penelitian ini berjumlah 10 perusahaan. Metode analisis data dilakukan menggunakan regresi sederhana dan regresi berganda dengan MRA. Hasil penelitian menunjukkan bahwa (1) Pengungkapan Corporate social responsibility secara parsial berpengaruh terhadap nilaiperusahaan perkebunan, (2) Profitabilitas secara parsial berpengaruh terhadap nilai perusahaan perkebunan, (3) Pengungkapan Corporate social responsibility dan profitabilitas dimoderasi oleh pengungkapan media berpengaruh secara simultan terhadap nilai perusahaan perkebunan, dan (4) Terdapat perbedaan pengaruh pengungkapan Corporate social responsibility dan profitabilitas yang dimoderasi oleh pengungkapan media pada perusahaan perkebunan yang terdaftar di bursa efek indonesia, malaysia dan singapura. Keterbatasan dalam penelitian ini adalah perbedaan sudut pandang peneliti dalam membaca laporan pengungkapan pertanggungjawaban karena perusahaan memiliki sudut pandang yang berbeda-beda dalam pelaporan.
\end{abstract}

Kata Kunci : CSR, Profitabilitas, Media Exposure, Nilai perusahaan 


\section{PENDAHULUAN \\ 1.1 Latar Belakang}

Peningkatan dalam kebutuhan minyak sawit berdampak pada subsektor perkebunan yang mengalami perkembangan yang semakin pesat dan besar serta diharapkan dapat meningkatkan pemenuhan produksi, kebutuhan ekspor yang berdampak pada peningkatan pendapatan petani, ekonomi lokal, pembangunan pedesaan, dan timbulnya multiplier effect secara sektoral maupun spasial baik nasional, regional maupun lokal. Pengembangan perkebunan ke arah agroindustri seharusnya memberikan dampak yang positif bagi perkembangan sektor dan wilayah, khususnya pembangunan ekonomi lokal.

Kasus pembakaran lahan secara besar-besaran pada tahun 2015 menyoroti perusahaan-perusahaan perkebunan di Indonesia. Pembukaan lahan baru dengan melakukan pembakaran hutan berdampak sangat buruk, bukan hanya di Indonesia tetapi juga ke negara tetangga seperti Singapura dan Malaysia. Kasus ini tidak sesuai dengan konsep triple bottom lines karena tidak memperhatikan orang-orang yang hidup di area perusahaan dan masalah lingkungan yang diakibatkan oleh aktivitas perusahaan. Hal yang dapat dilakukan dalam mengatasi permasalahan tersebut adalah dengan memberikan tanggung jawab sosial perusahaan atau Coorporate Social Responsibility (CSR) yang tepat.

Nilai perusahaan yang dibentuk melalui indikator pasar saham, sangat dipengaruhi oleh peluang-peluang investasi. (Brealey et al, 2007:46). Pengeluaran investasi dengan memberikan bantuan melalui dana CSR perusahaan dapat memberikan dampak positif tentang pertumbuhan perusahaan di masa yang akan datang, sehingga meningkatkan harga saham sebagai indikator nilai perusahaan (signaling theory).

Suatu perusahaan harus berada pada kondisi yang menguntungkan atau profitable agar tetap dapat menjalankan kegiatan operasional. Bukan hanya informasi mengenai pertanggungjawaban sosial, nilai perusahaan juga dapat dipengaruhi oleh profitabilitas yang dihasilkan oleh perusahaan. Salah satu ukuran kinerja perusahaan yang sering digunakan sebagai dasar pengambilan keputusan adalah laba yang dihasilkan oleh perusahaan (Subramanyam dan Wild, 2010).

Pengungkapan CSR melalui media dapat meningkatkan reputasi perusahaan di mata masyarakat (publik) sebagai salah satu pemegang saham. Hal ini dapat dijadikan sebagai bagian pada dalam proses membangun institusi, membentuk norma yang diterima dan legitimasi praktik CSR. Website memiliki peran sebagai salah satu media pengungkapan pelaporan dana CSR. Pelaporan pengelolaan CSR melalui website dapat diakses oleh semua orang sehingga transparansi dana dapat diamati dan meminimalisir pelaporan dana CSR fiktif.

\subsection{Rumusan Masalah}

Berdasarkan uraian yang dijelaskan pada latar belakang penelitian, maka permasalahan dalam penelitian ini dirumuskan sebagai berikut:

1. Apakah media exposure memoderasi hubungan antara pengungkapan corporate social responsibility dan profitabilitas terhadap nilai perusahaan perkebunan yang go public antara di Indonesia, Malaysia, dan Singapura?

2. Apakah pengungkapan corporate social responsibility secara parsial berpengaruh terhadap nilai perusahaan perkebunan yang go public di Indonesia, Malaysia dan Singapura?

3. Apakah profitabilitas secara parsial berpengaruh terhadap nilai perusahaan perkebunan yang go public di Indonesia, Malaysia dan Singapura?

4. Apakah terdapat perbedaan pengaruh pengungkapan corporate social responsibility di perusahaan perkebunan yang go public di Indonesia, Malaysia dan Singapura?

\section{TINJAUAN PUSTAKA, KERANGKA PEMIKIRAN DAN HIPOTESIS \\ 2.1 Tinjauan Pustaka \\ 2.1.1 Nilai Perusahaan}

Nilai perusahaan yang dibentuk melalui indikator pasar saham, sangat dipengaruhi oleh peluang-peluang investasi. Pengeluaran investasi memberikan sinyal positif dari investasi kepada manajer tentang pertumbuhan perusahaan di masa yang akan datang, sehingga meningkatkan harga saham sebagai indikator nilai perusahaan. Harga saham yang tinggi membuat nilai perusahaan juga tinggi (Brealey et al, 2007:46). Brigham dan Erdhadt (2005:518), nilai perusahaan merupakan nilai sekarang (present value) dari free cash flow di masa mendatang pada tingkat diskonto sesuai rata-rata tertimbang biaya modal.

\subsubsection{Pengungkapan Corporate Social Responsibility \\ Pengungkapan CSR adalah proses} pengkomunikasian dampak sosial dan lingkungan dari kegiatan ekonomi organisasi terhadap kelompok khusus yang berkepentingan dan masyarakat secara keseluruhan (Grey et al, 1987). Perusahaan melakukan pengungkapan informasi sosial dengan tujuan untuk membangun image pada perusahaan dan mendapatkan perhatian dari masyarakat. Beberapa teknik pengungkapan sosial seperti diungkapkan oleh Harahap (2006), yaitu: 
1. Pengungkapan dalam surat kepada pemegang saham baik dalam laporan tahunan atau dalam bentuk laporan lainnya.

2. Pengungkapan dalam catatan atas laporan keuangan.

3. Dibuat dalam perkiraan tambahan misalnya melalui adanya perkiraan (akun) penyisihan kerusakan lokasi, biaya pemeliharaan lingkungan dan sebagainya.

\subsubsection{Media Exposure (Pengungkapan Media)}

Media mempunyai peran penting pada pergerakan mobilisasi sosial, misalnya kelompok yang tertarik pada lingkungan (Patten, 2002 dalam Reverte, 2008). Menurut Simon (1992) dalam Reverte (2008), media adalah sumber daya pada informasi lingkungan. Perusahaan akan memanfaatkan media perusahaan untuk melakukan sesuatu yang akan menaikan nilai dari perusahaan seperti pengungkapan CSR, alasan pengungkapan CSR oleh perusahaan adalah untuk memperoleh keunggulan kompetitif, untuk memenuhi ketentuan kontrak pinjaman dan memenuhi ekspektasi masyarakat, untuk melegitimasi tindakan perusahaan, dan untuk menarik investasor (Sayekti dan Wondabio, 2007).

\subsubsection{Profitabilitas}

Profitabilitas adalah hasil akhir dari sejumlah kebijakan dan keputusan manajemen perusahaan (Brigham et al., 2001). Bagi perusahaan, meningkatkan profitabilitas adalah suatu keharusan agar saham perusahaan tetap menarik bagi investor. Para investor melakukan overview suatu perusahaan dengan melihat rasio keuangan sebagai alat evaluasi investasi, karena rasio keuangan mencerminkan tinggi rendahnya nilai perusahaan.

Apabila investor ingin melihat seberapa besar perusahaan menghasilkan return atas investasi yang mereka tanamkan, yang akan di lihat pertama kali adalah rasio profitabilitas, terutama $\mathrm{ROE}$, karena rasio ini mengukur seberapa efektif perusahaan menghasilkan return bagi para investor. ROE dibutuhkan investor untuk mengukur kemampuan perusahaan dalam memperoleh laba bersih yang berkaitan dengan dividen. Pemilihan ROE sebagai proksi dari profitabilitas adalah karena dalam ROE ditunjukkan, semakin tinggi ROE menunjukkan semakin efisien perusahaan dalam menggunakan modal sendiri untuk menghasilkan laba investor yang ditanam pada perusahaan (Van Horn dan John, 2005).

\subsection{Kerangka Pemikiran}

Tujuan utama perusahaan adalah meningkatkan nilai perusahaan. Nilai perusahaan akan terjamin tumbuh secara berkelanjutan apabila perusahaan memperhatikan dimensi ekonomi, sosial dan lingkungan hidup karena keberlanjutan merupakan keseimbangan antara kepentingan ekonomi, lingkungan dan masyarakat. Dimensi tersebut terdapat di dalam penerapan Corporate Social Responsibility yang dilakukan perusahaan sebagai bentuk pertanggungjawaban dan kepedulian terhadap lingkungan sekitar perusahaan. Hubungan antara pengungkapan tanggung jawab sosial terhadap nilai perusahaan telah diteliti oleh Nurlela dan Islahuddin (2008) serta Arafat et al (2012). Hasil penelitian menunjukkan bahwa terdapat hubungan positif antara pengungkapan tanggung terhadap nilai perusahaan.

Rasio keuangan menjadi salah satu overview sebagai alat evaluasi investasi karena rasio keuangan mencerminkan tinggi maupun rendahnya nilai perusahaan. Profitabilitas yang tinggi menunjukkan prospek perusahaan yang bagus sehingga memicu permintaan sahamoleh investor. Respon positif dari investor tersebut akan meningkatkan harga saham dan selanjutnya meningkatkan nilai perusahaan.

Profitabilitas yang di proksikan dengan Return On equity (ROE) menunjukan kemampuan perusahaan secara keseluruhan dalam menghasilkan laba dengan jumlah ekuitas yang ada di dalam perusahaan. Pengaruh positif dari profitabilitas terhadap nilai perusahaan ditunjukkan oleh hasil penelitian yang dilakukan oleh Hermuningsih (2013), Cecilia dkk (2015) dan Mahendra (2011).

Perusahaan tidak hanya memandang laba sebagai satu-satunya tujuan dari perusahaan, tetapi ada tujuan lain yaitu bentuk tanggung jawabnya kepada pihak stakeholder, karena perusahaan mempunyai tanggung jawab yang lebih luas dibandingkan hanya mencari laba untuk mencari laba untuk pemegang saham (Gray et. Al, :1987).

\subsection{Hipotesis}

Hipotesis penelitian ini adalah sebagai berikut:

$\mathrm{H}_{1}$ : Pengungkapan Corporate social responsibility dan profitabilitas dimoderasi oleh pengungkapan media berpengaruh secara simultan terhadap nilai perusahaan perkebunan yang go public antara di Indonesia, Malaysia, dan Singapura.

$\mathrm{H}_{2}$ : Pengungkapan Corporate social responsibility secara parsial berpengaruh terhadap nilai perusahaan perkebunan yang go public di Indonesia, Malaysia dan Singapura.

$\mathrm{H}_{3}$ : Profitabilitas secara parsial berpengaruh terhadap nilai perusahaan perkebunan yang go public di Indonesia, Malaysia dan Singapura.

$\mathrm{H}_{4}$ : Terdapat perbedaan pengaruh pengungkapan Corporate social responsibility dan profitabilitas yang dimoderasi oleh pengungkapan media pada nilai perusahaan perkebunan yang go public di Indonesia, Malaysia, dan Singapura. 


\section{METODOLOGI PENELITIAN}

\subsection{Populasi dan Sampel}

Populasi yang menjadi objek dalam penelitian ini adalah seluruh perusahaan perkebunan yang terdaftar di Bursa Efek Indonesia, Malaysia dan Singapura selama tahun 2014-2017. Populasi pada penelitian ini berjumlah 37 perusahaan yang terdiri dari 15 perusahaan listing di Indonesia, 15 perusahaan listing di Malaysia dan 7 perusahaan listing di Singapura. Terdapat 10 perusahaan perkebunan yang berhasil memenuhi kriteria sebagai sampel pada penelitian ini. Perusahaan yang memenuhi kriteria tersebut yaitu 4 perusahaan perkebunan di Indonesia, 3 perusahaan perkebunan di Malaysia dan 3 perusahaan perkebunan di Singapura.

\subsection{Variabel dependen}

Variabel dependen dalam penelitian ini adalah nilai perusahaan. Persepsi investor terhadap perusahaan, yang sering dikaitkan dengan harga saham. Nilai perusahaan yang dibentuk melalui indikator pasar saham, sangat dipengaruhi oleh peluang-peluang investasi (Brealey et al, 2007:46). Nilai perusahaan dalam penelitian ini dikonfirmasikan melalui Tobin's $Q$ ratio. Rumus untuk menghitung nilai perusahaan adalah sebagai berikut:

$T Q=\frac{\text { Nilai Pasar Ekuitas }+ \text { Total Kewajiban }}{\text { Total Aset }}$

Keterangan:

TQ

Nilai Pasar Ekuitas

: Tobbin's Q Ratio

: Jumlah saham yang beredar $\mathrm{x}$ harga per lembar saham

\subsection{Variabel Independen}

a. Corporate Social Responsibility (CSR)

Pengukuran Corporate Social Responsibility mengacu pada 91 item pengungkapan yang terbagi menjadi 3 kategori dan 4 sub kategori menurut GRI, yaitu:

1. Ekonomi, meliputi 9 item

2. Lingkungan, meliputi 34 item

3. Sosial meliputi

- Praktek Ketenagakerjaan yang Layak meliputi 16 item

- Hak Asasi Manusia meliputi 12 item

- Kemasyarakatan meliputi 11 item

- Tanggung Jawab Produk meliputi 9 item

Perhitungan formula CSRI (CSR Index) menurut Sembiring (2005) adalah sebagai berikut :

$$
\operatorname{CSRIj}=\frac{\sum X i j}{n i j}
$$

Keterangan :

$\mathrm{CSRI}_{\mathrm{j}}:$ CSR Index perusahaan $\mathrm{j}$ $\sum X_{\mathrm{ij}}$ : banyaknya item yang diungkapkan oleh perusahaan $\mathrm{j}$

$n_{j} \quad:$ total item untuk perusahaan $\mathrm{j}, \mathrm{nj} \leq 91$

b. Profitabilitas

Profitabilitas merupakan kemampuan perusahaan untuk menghasilkan laba dalam upaya meningkatkan nilai pemegang saham (Setiawan, 2010). Return on equity menunjukkan kemampuan perusahaan dalam menghasilkan laba atas total ekuitas yang dimilikinya. Rumus untuk menghitung ROE adalah sebagai berikut:

$$
\text { ROE }=\frac{\text { laba bersih }}{\text { total ekuitas }}
$$

\subsection{Variabel Moderating}

Variabel moderating pada penelitian ini adalah media exposure. Media merupakan alat bagi perusahaan untuk melakukan komunikasi dengan para stakeholdersnya, melalui media perusahaan dapat membagikan informasi mengenai kondisi perusahan tersebut. Pengukuran media exposure pada penelitian ini dengan menggunakan variabel dummy. Penelitian ini memberikan nilai 1 untuk perusahaan yang mengungkapkan kegiatan CSR di website perusahaan dan 0 untuk perusahaan yang tidak mengungkapkan kegiatan CSR di website perusahaan.

\section{HASIL DAN PEMBAHASAN \\ 4.1. Hasil Penelitian \\ 4.1.1 Uji Normalitas \\ Hasil uji normalitas dalam penelitian ini ditunjukkan pada Tabel 1 berikut :}

Tabel 1. Uji Normalitas

\begin{tabular}{|c|c|c|}
\hline & & $\begin{array}{c}\text { Unstandardized } \\
\text { Residual }\end{array}$ \\
\hline \multicolumn{2}{|l|}{$\mathrm{N}$} & 40 \\
\hline \multirow[t]{2}{*}{ Normal Parameters $^{\mathrm{a}}$} & Mean & .0000000 \\
\hline & $\begin{array}{l}\text { Std. } \\
\text { Deviation }\end{array}$ & .46447734 \\
\hline \multirow{3}{*}{$\begin{array}{l}\text { Most Extreme } \\
\text { Differences }\end{array}$} & Absolute & .121 \\
\hline & Positive & .068 \\
\hline & Negative & -.121 \\
\hline \multicolumn{2}{|c|}{ Kolmogorov-Smirnov Z } & .766 \\
\hline \multicolumn{2}{|l|}{ Asymp. Sig. (2-tailed) } & .601 \\
\hline
\end{tabular}

One-Sample Kolmogorov-Smirnov Test

a. Test distribution is Normal.

Sumber : Hasil Olahan Data SPSS, 2018

Hasil One Sample Kolmogorov Smirnov Test pada tabel $1 \mathrm{di}$ atas menunjukkan nilai Kolmogorov Smirnov $=0,766$ dengan probabilitas 0,601 (Asymp.Sig.(2-tailed). Persyaratan data tersebut normal jika probabilitas atau $\mathrm{p}=0,601>0,05$ sehingga dapat disimpulkan bahwa data yang uji berdistribusi normal. 


\subsubsection{Uji Multikolonieritas}

Hasil pengujian dapat dilihat pada tabel 2 berikut ini:

Tabel 2.

Hasil Uji Multikolonieritas

\begin{tabular}{|c|c|c|c|}
\hline \multicolumn{4}{|c|}{ Coefficients ${ }^{a}$} \\
\hline \multirow{2}{*}{\multicolumn{2}{|c|}{ Model }} & \multicolumn{2}{|c|}{ Collinearity Statistics } \\
\hline & & Tolerance & VIF \\
\hline \multirow[t]{3}{*}{1} & CSR & .817 & 1.224 \\
\hline & ROE & .788 & 1.269 \\
\hline & MEDIA & .950 & 1.052 \\
\hline
\end{tabular}

a. Dependent Variable: NILAI

Sumber: Hasil Olahan Data SPSS, 2018.

Berdasarkan hasil pengujian multikolonieritas pada tabel 2 menghasilkan nilai Tolerance $>0,1$ dan nilai VIF < 10. Hal ini berarti tidak ada multikolonieritas antar variabel independen dalam model regresi.

\subsubsection{Uji Heteroskedastisitas} berikut ini:

Hasil pengujian dapat dilihat pada Gambar 1

Gambar 1.

Hasil Uji Heteroskedastisitas

Scatterplot

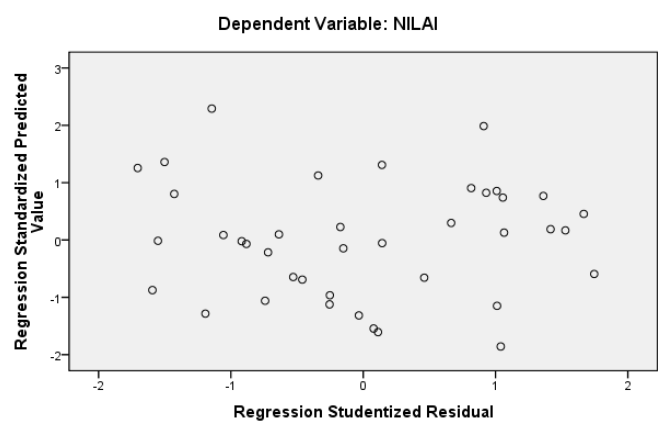

Sumber : Hasil Olahan Data SPSS, 2018

Berdasarkan grafik scatterplot di atas tampak bahwa sebaran data menyebar baik dan tidak membentuk pola yang jelas, titik-titik data menyebar di atas dan di bawah angka 0 pada sumbu Y. Hal ini mengindikasikan bahwa pada uji ini tidak terjadi heteroskedastisitas dalam model regresi.

\subsection{Analisis Data}

\subsubsection{Uji Statistik t Hipotesis 2} berikut ini:
Tabel 3.

Hasil Uji Statistik t Hipotesis 2

Coefficients

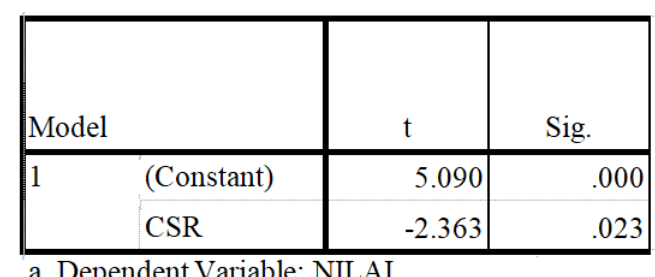

Sumber: Hasil Olahan Data SPSS, 2018.

Hasil uji t pada tabel 3 menjelaskan bahwa pengaruh pengungkapan CSR terhadap nilai perusahaan pada perusahaan perkebunan memperoleh angka sebesar 2,363 lebih tinggi dibandingkan $t$ tabel 1,688. Taraf signifikansi 0,023 menunjukkan nilai signifikan < 0,05 . Dengan demikian, jawaban untuk rancangan hipotesis 2 yaitu menerima $\mathrm{H}_{2}$ dan menolak $\mathrm{H}_{0}$. Sehingga dapat disimpulkan bahwa terdapat pengaruh signifikan variabel profitabilitas terhadap nilai perusahaan pada perusahaan perkebunan.

\subsubsection{Uji Statistik t Hipotesis 3}

Hasil uji statistik t Hipotesis 3 dapat dilihat pada tabel 4berikut ini:

Tabel 4.

Hasil Uji Statistik t Hipotesis 2

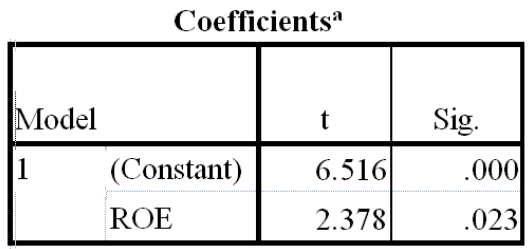

a. Dependent Variable: NILAI

Sumber: Hasil Olahan Data SPSS, 2018.

Hasil uji t pada tabel 4 menjelaskan bahwa pengaruh profitabilitas terhadap nilai perusahaan pada perusahaan perkebunan memperoleh angka sebesar 2,378 lebih tinggi dibandingkan $\mathrm{t}$ tabel 1,688. Taraf signifikansi 0,023 menunjukkan nilai signifikan $<0,05$. Dengan demikian, jawaban untuk rancangan hipotesis 3 yaitu menerima $\mathrm{H}_{3}$ dan menolak $\mathrm{H}_{0}$. Sehingga dapat disimpulkan bahwa terdapat pengaruh signifikan variabel pengungkapan CSR terhadap nilai perusahaan pada perusahaan perkebunan.

\subsubsection{Uji F}

Uji $F$ digunakan untuk menguji apakah variabel pengungkapan CSR $\left(\mathrm{X}_{1}\right)$, ROE $\left(\mathrm{X}_{2}\right)$ dengan dimoderasi oleh pengungkapan media $\left(\mathrm{X}_{3}\right)$ secara simultan atau bersama-sama mempunyai pengaruh yang signifikan 
terhadap nilai perusahaan perkebunan. Hasil uji F dapat dilihat pada tabel 5 berikut :

Tabel 5.

Hasil Uji F

ANOVA $^{\text {b }}$

\begin{tabular}{|ll|r|r|}
\hline \multicolumn{2}{|l|}{ Model } & F & Sig. \\
\hline 1 & Regression & 3.347 & $.015^{\mathrm{a}}$ \\
& Residual & & \\
& Total & & \\
& & & \\
\hline
\end{tabular}

a. Predictors: (Constant), X2X3, CSR, ROE, MEDIA,

$\mathrm{X} 1 \mathrm{X} 3$

b. Dependent Variable: NILAI

Sumber : Hasil Olahan Data SPSS, 2018.

Nilai F dan taraf signifikansi yang diperoleh pada tabel 5 di atas akan menjawab rancangan hipotesis 1 pada penelitian ini yaitu menerima $\mathrm{H}_{1}$ dan menolak $\mathrm{H}_{0}$. Hasil uji $\mathrm{F}$ pada tabel 4.14 memperoleh angka sebesar 3,347 lebih tinggi dibandingkan $\mathrm{F}$ tabel 2,86. Taraf signifikansi 0,015 menunjukkan nilai signifikan $<0,05$. Kondisi ini membawa pada suatu kesimpulan bahwa pengungkapan corporate social responsibility dan profitabilitas dengan dimoderasi oleh media exposure terhadap nilai perusahaan perkebunan yang go public antara di Indonesia, Malaysia, dan Singapura secara simultan atau bersama-sama memiliki pengaruh yang signifikan.

\subsubsection{Uji One Sample Test}

Uji One Sample $\mathrm{T}$ Test digunakan untuk mengetahui apakah terdapat perbedaan dalam pengungkapan CSR yang terdapat di negara Indonesia, Malaysia dan Singapura. Hasil Uji One Sample T Test dapat dilihat pada tabel 6 berikut :

Tabel 6.

\section{Uji One Sample T Test}

\begin{tabular}{|l|r|r|r|r|}
\hline \multicolumn{1}{|c|}{ One-Sample Test } \\
\hline & \multicolumn{4}{|c|}{ Test Value $=0.63$} \\
\cline { 2 - 5 } & $\mathrm{t}$ & $\mathrm{df}$ & $\begin{array}{r}\text { Sig. (2- } \\
\text { tailed) }\end{array}$ & $\begin{array}{c}\text { Mean } \\
\text { Difference }\end{array}$ \\
\hline CSR & 5.214 & 39 & .000 & .08275 \\
\hline
\end{tabular}

Sumber : Hasil Olahan Data SPSS, 2018.

Tabel 6 menunjukkan bahwa didapatkan nilai $t$ hitung sebesar 5,214 dengan derajat bebas 39 (n-1) dengan nilai Sig (2-tailed) sebesar 0,000. Nilai t-tabel dengan derajat bebas 39 dengan taraf signifikansi sebesar $0,05(5 \%)$ adalah sebesar 0,000 . Nilai signifikansi menunjukkan bahwa $0,000<0,005$ dan nilai t hitung menunjukkan 5,214>1,684. Hal ini membuktikan bahwa terdapat perbedaan pelaporan pengungkapan CSR pada perusahaan perkebunan di Negara Indonesia, Singapura dan Malaysia. Perbedaan ini terjadi karena sudut pandang masing-masing perusahaan dalam membuat laporan pertanggung jawaban sosial.

\subsection{Pembahasan}

Pengaruh Pengungkapan Corporate Social Responsibility dan Profitabilitas Dimoderasi oleh Pengungkapan Media Berpengaruh Secara Simultan Terhadap Nilai Perusahaan Perkebunan yang Go Public di Indonesia, Malaysia dan Singapura.

Hasil analisis regresi linear berganda menunjukkan bahwa Nilai F memperoleh angka sebesar 3,347lebih tinggi dibandingkan $F$ tabel 2,84. Taraf signifikansi 0,015 menunjukkan nilai signifikan $<0,05$. Kondisi ini membawa pada suatu kesimpulan bahwa pengungkapan corporate social responsibility dan profitabilitas dengan dimoderasi oleh media exposure terhadap nilai perusahaan perkebunan yang go public antara di Indonesia, Malaysia, dan Singapura secara simultan atau bersama-sama memiliki pengaruh yang signifikan.

Akses terhadap media yang semakin mudah saat ini dapat menjadi salah satu langkah perusahaan dalam menyampaikan informasi dan menarik investor melalui informasi yang disajikan. Penggunaan website sebagai salah satu media menjadi lebih praktis. Informasi mengenai perusahaan dapat diakses secara lengkap. Laporan yang disajikan di website perusahaan tidak hanya meliputi laporan keuangan, namun juga laporan pertanggung jawaban, artikel dan berita mengenai perkembangan perusahaan serta statistik perusahaan yang terbaru.

Pengaruh Pengungkapan Corporate Social Responsibility Secara Parsial Berpengaruh Terhadap Nilai Perusahaan Perkebunan yang Go Public di Indonesia, Malaysia dan Singapura

Hasil analisisi regresi linear berganda menunjukkan bahwa Pengaruh pengungkapan CSR terhadap nilai perusahaan pada perusahaan perkebunan memperoleh angka sebesar 2,363 lebih tinggi dibandingkan $t$ tabel 1,688. Taraf signifikansi 0,023 menunjukkan nilai signifikan $<0,05$. Hasil penelitian ini sesuai dengan penelitian Nurlela \& Islahuddin (2008) dan Arafat et al (2012).

Perusahaan melakukan pengungkapan informasi sosial dengan tujuan untuk membangun image pada perusahaan dan mendapatkan perhatian dari 
masyarakat. CSR merupakan strategi jangka panjang yang dibentuk oleh perusahaan.. Kepercayaan yang dilabeli oleh masyarakat akan meyakinkan investor akan keberlangsungan hidup perusahaan. CSR yang dilakukan oleh perusahaan perkebunan pada penelitian ini mulai dari pemberian bibit tanaman, beasiswa hingga fasilitas kesehatan. Kegiatan-kegiatan CSR yang dilakukan oleh perusahaan pada akhirnya akan mendapat perhatian baik dari masyarakat maupun investor.

Pengaruh Profitabilitas Secara Parsial Terhadap Nilai Perusahaan Perkebunan yang Go Public di Indonesia, Malaysia Dan Singapura

Hasil analisis regresi berganda menunjukkan bahwa pengaruh ROE terhadap nilai perusahaan pada perusahaan perkebunan memperoleh angka sebesar 2,378 lebih tinggi dibandingkan $\mathrm{t}$ tabel 1,688. Taraf signifikansi 0,023 menunjukkan nilai signifikan $<0,05$. Sehingga dapat disimpulkan bahwa terdapat pengaruh signifikan variabel ROE terhadap nilai perusahaan pada perusahaan perkebunan. Hal tersebut berarti bahwa semakin tinggi tingkat ROE maka nilai perusahaan juga akan semakin meningkat.

Hasil penelitian ini sesuai dengan penelitian yang di lakukan oleh Mahendra (2011), Arafat et al (2012) dan Hermuningsih (2013). Semakin baik perusahaan membayar return terhadap pemegang saham akan meningkatkan nilai perusahaan. Profitabilitas secara parsial dalam hasil penelitian ini menemukan bahwa profitabilitas berpengaruh positif signifikan terhadap nilai perusahaan. Profitabilitas menunjukkan tingkat keuntungan bersih yang mampu diraih oleh perusahaan pada saat menjalankan operasinya. Semakin besar ROE, semakin besar pula tingkat keuntungan yang dicapai perusahaan sehingga kemungkinan suatu perusahaan dalam kondisi bermasalah semakin kecil.

Perbedaan Pengaruh Pengungkapan Corporate Social Responsibility Dan Profitabilitas Yang Dimoderasi Oleh Pengungkapan Media Pada Nilai Perusahaan Perkebunan Yang Go Public Di Indonesia, Malaysia, Dan Singapura

Hasil analisis One Sample Test menunjukkan bahwa terdapat perbedaan pelaporan pengungkapan CSR antara perusahaan perkebunan di negara Indonesia, Malaysia dan Singapura. Hal ini dibuktikan dengan nilai signifikansi dari 3 kelompok negara tersebut sebesar $0,000<0,05$. Perbedaan dapat dilihat dari persentase indikator CSR yang bervariasi di tiaptiap negara.

Empat perusahaan perkebunan di Indonesia yang menjadi sampel pada penelitian ini rata-rata skor pelaporannya yaitu sebesar $72,44 \%$ atau 65 item. Tiga perusahaan perkebunan di Malaysia yang terdapat pada penelitian ini rata-rata skor pelaporannya yaitu sebesar
$68,08 \%$ atau 62 item. Perusahaan perkebunan di Indonesia yang terdapat pada penelitian ini rata-rata skor pelaporannya yaitu sebesar $72,97 \%$ atau 66 item.

\section{KESIMPULAN DAN SARAN}

\subsection{Simpulan}

Kesimpulan yang diperoleh pada penelitian ini adalah :

1. Pengungkapan Corporate social responsibility secara parsial berpengaruh terhadap nilai perusahaan perkebunan yang go public di Indonesia, Malaysia dan Singapura.

2. Profitabilitas secara parsial berpengaruh terhadap nilai perusahaan perkebunan yang go public di Indonesia, Malaysia dan Singapura.

3. Pengungkapan Corporate social responsibility dan profitabilitas dimoderasi oleh pengungkapan media berpengaruh secara simultan terhadap nilai perusahaan perkebunan yang go public antara di Indonesia, Malaysia, dan Singapura.

4. Terdapat perbedaan pengaruh pengungkapan Corporate social responsibility dan profitabilitas yang dimoderasi oleh pengungkapan media pada nilai perusahaan perkebunan yang go public di Indonesia, Malaysia, dan Singapura.

\subsection{Saran}

Adapun saran-saran yang dapat diberikan melalui hasil penelitian ini agar mendapatkan hasil yang lebih baik, yaitu:

1. Penelitian selanjutnya diharapkan menggunakan penerapan Good Corporate Governance (GCG) selain Corporate Social Responsibility (CSR) sebagai variabel bebas dalam pengaruhnya terhadap nilai perusahaan.

2. Pengaruh variabel pengungkapan $\operatorname{CSR}\left(\mathrm{X}_{1}\right)$, profitabilitas $\left(\mathrm{X}_{2}\right)$ dan media pengungkapan $\left(\mathrm{X}_{3}\right)$ hanya sebesar $23,1 \%$ terhadap variabel nilai perusahaan (Y). Sedangkan sisanya yaitu sebesar $76,9 \%$ dipengaruhi oleh variabel lain yang tidak diikutsertakan dalam penelitian ini. Penelitian selanjutnya diharapkan untuk mengganti variabelvariabel lain baik itu rasio keuangan maupun non rasio keuangan sehingga bisa diteliti faktor-faktor yang mempengaruhi nilai perusahaan lebih besar.

3. Penelitian selanjutnya diharapkan menggunakan perusahaan berbeda, seperti perusahaan pertambangan yang juga membutuhkan perhatian lingkungan. 


\section{DAFTAR REFERENSI}

Brealey, et al. 2007.Dasar-Dasar Manajemen Keuangan. Jakarta: Penerbit Erlangga.

Brigham, E.F dan J.F. Houston. 2006. Dasar-Dasar Manajemen Keuangan. Edisi Kesepuluh. Jakarta : Salemba Empat.

Harahap, Sofyan. 2006. Analisis Kritis Atas Laporan Keuangan Edisi Pertama. Jakarta : Raja Grafindo Persada.

Gray et al. 1987. Social and Environmental Disclosure and Corporate. Characteristic: A Research Note and Extension. Journal of Cusiness.

Van Horn, James C, dan John M. Wachowicz, Jr. 2005. Fundamentals of Financial Manajement (Prinsip Manajemen Keuangan). Edisi Kedua Belas, Buku satu. Jakarta : Salemba Empat.

Sembiring, 2005. Karakteristik Perusahaan dan Pengungkapan Tanggung jawab Sosial: Studi Empiris pada Perusahaan yang tercatat di Bursa Efek Jakarta. Paper Presented at the Seminar Nasional Akuntansi, Solo.

Hermuningsih, Sri. 2013. Pengaruh Profitabilitas, Growth Opportunity, Sruktur Modal Terhadap Nilai Perusahaan Pada Perusahaan Publik di Indonesia. Buletin Ekonomi Moneter dan Perbankan, Oktober 2013.

Cecilia, Rambe M, Syahrul dan Zainul Bahri Torong. 2015. Analisis Pengaruh Corporate Social Responsibility, Profitabilitas Dan Ukuran Perusahaan Terhadap Nilai Perusahaan Pada Perusahaan Perkebunan Yang Go Public Di Indonesia, Malaysia, Dan Singapura. Simposium Nasional Akuntansi XVIII.

Mahendra DJ, Alfredo. 2011. Pengaruh Kinerja Keuangan Terhadap Nilai Perusahaan (Kebijakan Dividen Sebagai Variabel Moderating) Pada Perusahaan Manufaktur Di Bursa Efek Indonesia. Tesis. Universitas Udayana.

Arafat et al., 2012. The Triple Bottom Line Effect on Emerging Market Companies: A Test of Corporate Social Responsibility and Firm Value Relationship, Journal of Southeast Asian Research (2012).
Setiawan Iwan, 2010. Akuntansi Keuangan Menengah (Intermediate acounting), Buku Satu, Bandung :Refika Aditama.

Nurlela, Rika dan Islahuddin. 2008. Pengaruh Corporate Social Responsibility Terhadap Nilai Perusahaan Dengan Prosentase Kepemilikan Manajemen Sebagai Variabel Moderating (Studi Empiris Pada Perusahaan Yang Terdaftar Di Bursa Efek Jakarta). Simposium Nasional Akuntansi XI. 23-24 Juli 2008. Pontianak.

Sayekti, Y. dan L. S. Wondabio. 2007. "Pengaruh CSR Disclosure terhadap Earning Response Coefficient". Simposium Nasional Akuntansi X. Makassar, 26-28 Juli.

Reverte, Carlo. 2008. Determinants of Corporate Social Responsibility Disclosure Ratings by Spanish Listed Firms. Journal of Business Ethics 88:351.

Subramanyam, KR dan John, J. Wild, 2010. Analisis Laporan Keuangan, Buku Satu, Edisi Sepuluh, Salemba Empat, Jakarta.

Yao, R., Sharpe, D. L., \& Wang, F. (2011). Decomposing the Age Effect on Risk Tolerance. The Journal of Socio-Economics, 40, 879-887. 